\title{
Lise ve Üniversite Öğrencilerinde Sınav Kaygısının Karşılaştırılması
}

\section{Comparison of Test Anxiety in High School and University Students}

\author{
Uğur DOĞAN ${ }^{1}$
}

\begin{tabular}{|c|c|}
\hline $\begin{array}{l}\text { Anahtar Kelimeler } \\
\text { Sinav kaygisl, } \\
\text { Lise ögrencileri, } \\
\text { Üniversite } \\
\text { ögrencileri. }\end{array}$ & 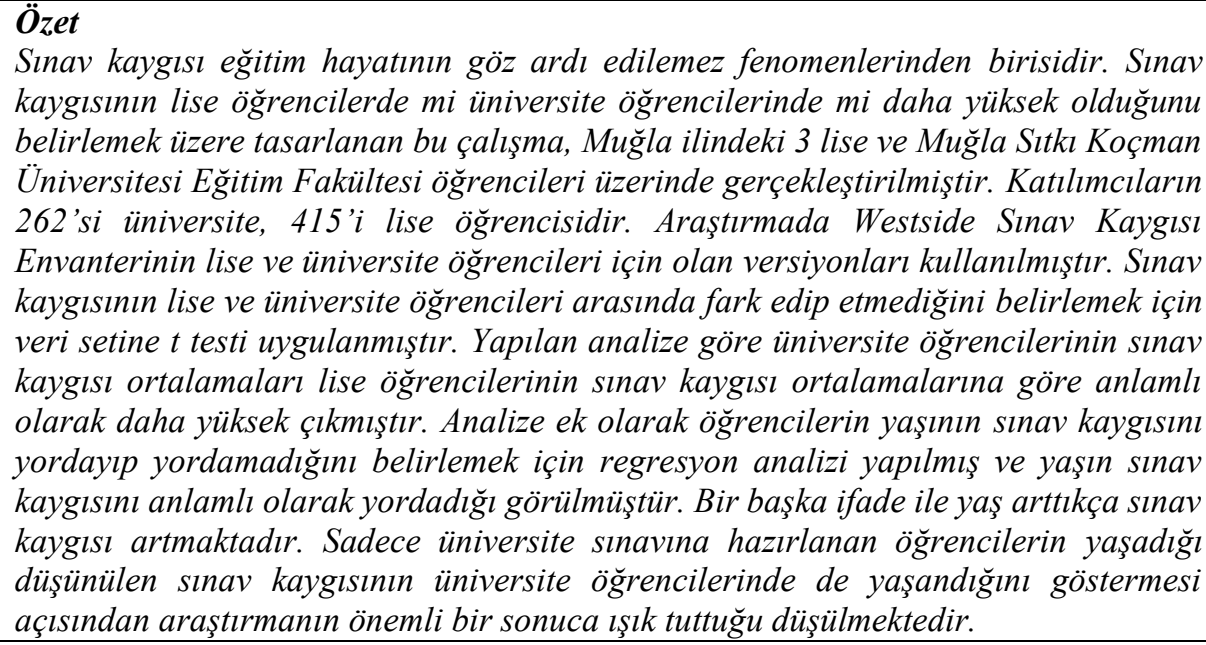 \\
\hline $\begin{array}{l}\frac{\text { Key Word }}{\text { Test anxiety, }} \\
\text { High school students, } \\
\text { University students. }\end{array}$ & $\begin{array}{l}\text { Abstract } \\
\text { Test anxiety is one of the indispensable phenomena of education. The aim of this study } \\
\text { determines whether test anxiety was higher in high school students or university } \\
\text { students. The study was carried out on three high schools in Muğla and Muğla Sitkl } \\
\text { Koçman University Faculty of Education. Participants are } 262 \text { university students, } \\
\text { and } 415 \text { of them are high school students. In the current study, the high school and } \\
\text { university form of the Westside Test Anxiety Inventory was used. The t-test was applied } \\
\text { to the data set to determine whether the test anxiety was different between high school } \\
\text { and university students. According to the analysis, the test anxiety of university } \\
\text { students was higher than the test anxiety of high school students. Besides, a regression } \\
\text { analysis was conducted to determine whether the age of the students predicted the test } \\
\text { anxiety and it was found that age significantly predicted the test anxiety. In other } \\
\text { words, the test anxiety increases with age. It is considered that the study sheds light } \\
\text { on a significant result in terms of showing that the test anxiety which is thought to be } \\
\text { experienced only by the students preparing for the university exam, is also experienced } \\
\text { in university students. }\end{array}$ \\
\hline
\end{tabular}

Atıf için: $\quad$ Doğan, U. (2020). Lise ve Üniversite Öğrencilerinde Sınav Kaygısının Karşılaştırılması. Muğla For Citation Sitkı Koçman Üniversitesi Eğitim Fakültesi Dergisi [MSKU Journal of Education],7 (1), 3542. DOI: $10.21666 /$ muefd.637421

Received: 23.10.2019 Accepted: 18.03.2020 $\quad$ Published: 01.05.2020

Sınav Kaygısı, kaygının sınavlara ve diğer performans değerlendirmesinin olduğu durumlara özgü bir şeklidir. Sınavları tehdit edici bir durum olarak değerlendirme eğilimi olarak tanımlanır ve bireyi değerlendirme ile değerlendirme zamanlarında yüksek düzeyde durumluk kaygı yaşamaya yatkın hale getirir (Putwain ve Daly, 2014; Spielberger ve Vagg, 1995). Bu, dinamik bir şekilde yaşanan, bireye özgü olan ve yaşadıkları durumun değerlendirmelerini içeren bir dizi bilişsel ve fizyolojik reaksiyonu beraberinde getirir (Whitaker Sena, Lowe ve Lee, 2007; Zeidner, 1998). Sınav kaygis1 endişe boyutu

\footnotetext{
${ }^{1}$ Muğla Sıtkı Koçman Üniversitesi Eğitim Fakültesi, ugurdogan@mu.edu.tr, ORCID: 0000-0001-7603-6470
} 
zamanla ilgisiz düşünmeyi test etme ile gelişen, gerginlik ve bedensel belirtileri içeren yaygın olarak kabul görmekte olan karmaşık bir yapıdır.

McDonald (2001) sınav kaygısının kaynaklarını araştııırken yaygın olarak "başarısızlık ve eleştiri korkusu", "sınav olma" ve "sınavda başarısız olma" olgularını bulmuştur. Zeidner (1998), sınav kaygısını "bir sınav veya değerlendirme durumuna bağlı olası olumsuz sonuçlara ilişkin endişeye eşlik eden bilişsel, duyuşsal ve davranışsal reaksiyonlar kümesi”, Nicaise (1995) ve Whitaker Sena ve diğ. (2007) sınav kaygısının "bir bireyin, bir değerlendirme hakkındaki olumsuz duyguları teşvik eden fizyolojik, bilişsel ve davranışsal tepkileri” olduğunu öne sürerler. Suinn (1968) sınav kaygısını, etkisinin bir kısmını kapsayacak şekilde tanımlamıştır: "düşünme veya hatırlama yetersizliği, inceleme sırasında basit cümleleri veya yönleri okurken, anlarken bir gerginlik ve zorluk hissi”. Sarason (1978) sınav kaygısını; görev ile ilgisiz davranış olarak betimler; "Birey kendi performansının değerlendirildiği konusunda farkındalığı arttırdığı zaman kişiselleştirilmiş görev-ilgisiz tepkiler verme eğilimidir”. Buck (2017)'ye göre ise sınav kaygısı, bireylerin sinavları ve testleri tehdit olarak yorumlamaya yatkın olmalarına neden olan bir kişilik özelliği olarak kabul edilir. Performans değerlendirme durumlarında, bu durum, artan düzeyde sürekli kaygı ve bununla ilişkili bir dizi bilişsel, fizyolojik ve davranışsal tepkiler yaşamalarına neden olur.

Sınav kaygısı yapısı ilk olarak 1950'lerde araştırılmaya başlanmıştır. Mandler ve Sarason (1952)'un çalışması, sınav kaygısını bağımsız bir yapı olarak ilk ele alan çalışmalardan birisidir (Hembree, 1988); o zamandan beri konuya olan ilgi artmaktadır (Zeidner, 1998). Sınav kaygısı araştırmaları, 1970'lerin başından sonuna kadar, 1980'lerin başında, akademik performans üzerindeki etkisine yönelik nedensel bir mekanizma tanımlamak ve bu etkiyle başa çıkmak için müdahaleler geliştirmek için girişimlerde bulunarak zirveye ulaşmıştır (Zeidner, 1998). Bu süreden sonra araştırma hacmindeki düşüşe rağmen, son yıllarda hesap verme sorumluluğunun artması ve müfredatın sonuçlarının daha da artmasıyla sonuçlanan politika değişikliklerine bağlı olarak araştırmalar sınav kaygısı alanında yeniden ortaya çıkmıştır (Putwain, 2008).

İlk yapılan sınav kaygısı araştırmaları kavramı motivasyonel bir yapı olarak görmüş ve psikolojik dürtüler etrafın odaklanmış ve genel kaygının bir yansıması olarak ele almıştır. (Mandler ve Sarason, 1952; Spence ve Spence, 1966). Araştırmalar 1960'ların sonlarında bilişsel bir kaygı modeline doğru kaymıştır; örneğin, Liebert ve Morris (1967) bilişsel-dikkatsel bir fenomen olarak sınav kaygısı kuramlarına öncülük etmiştir (Sarason, 1978; Wine, 1971). Bu teoriler, bir bireyin dikkatini, göreve ilişkin düşünceler (örneğin, bir görevin gereksinimlerini ele alma) ile göreve ilişkin olmayan düşünceler (örneğin performansları ve/veya başarısızlığın sonuçları hakkında endişeler) arasında bölünmesi gerektiğini önermektedir. Bu dikkat bölünmesinin sınav performansı üzerinde olumsuz bir etkisi olduğu öne sürülmüştür (Wine, 1971). 1980'lerde bu beceri açı̆̆ı paradigması diğer araştırmacıların ilgisini çekmiştir (Culler ve Holahan, 1980; Kirkland ve Hollandsworth, 1980; Naveh-Benjamin, McKeachie, Lin ve Holinger, 1981). Bu, akademik çalışmaların düzenlenmesi, sınavlara çalışma veya sınav olma becerileri konusunda zayıf öz düzenlemeye sahip olan öğrenciler, sınavlarda düşük performans gösterirler $\mathrm{Bu}$, sınav kaygısının, akademik zorluklarının bir nedeni olmak yerine, gerekli becerilerin eksikliği nedeniyle tekrarlanan başarısızlık deneyimlerinin bir sonucu olduğunu ileri sürmüştür.

Birçok faktörün etki edebildiği sınavların okul düzeyleri arasında farklılaşıp farklılaşmadığının tespitine yönelik alanyazın incelendiğinde herhangi bir çalışmaya rastlanılmamıştır. Araştırma olmamasının yanında sınav kaygısı denilince ilk akla gelen üniversite sınavına hazırlanan ögrencilerdir, diğer grup ise lise sınavına hazırlanan öğrencilerdir. Üniversite öğrencileri sınav kaygısı ile birlikte anılmamaktadır. Bu açıdan bakıldığında çalışmanın amacı üniversite sınavına girecek lise son sınıf öğrencileri ile KPSS sınavına girecek üniversite son sınıf öğrencilerinin sınav kaygılarını karşılaştırmaktır.

\section{Çalışma Grubu}

\section{Yöntem}

Lise öğrencileri ile üniversite öğrencilerinin sınav kaygılarında fark olup olmadığını belirlemeye yönelik olarak tasarlanan çalı̧̧ma için Muğla Sitkı Koçman Üniversitesi Eğitim Fakültesi'nin son sınıfına devam eden öğrencilerden ve Muğla ili Menteşe ilçesindeki 3 lisede öğrenimlerine devam eden lise öğrencilerinden veri toplanmıştır. Çalışmanın katılımcıları 364'ü kadın $(\% 54,9), 299$ 'u erkek $(\% 45,1)$ olmak üzere toplam 677 kişiden oluşmaktadır (14 katılımcı cinsiyetini belirtmemiştir). Katılımcıların 262'si üniversite $(\% 38,5)$ 415'i lise (\%61,5) öğrencisidir. Lise öğrencilerinin 176's1 kadın $(\% 43,7)$ 
227 'si erkek (\%56,3) öğrencidir (12 öğrenci cinsiyetini belirtmemiştir). Lise öğrencilerin yaşları 15 ile 22 arasında değişmektedir (Ort: 17,1, Ss: 0.81). Üniversite öğrencilerinin 188'si kadın (\%72,3) 72'si erkek $(\% 27,7)$ öğrencidir. Üniversite öğrencilerin yaşları 21 ile 32 arasında değişmektedir (Ort: 22,3, Ss:2.77). Araştırmada amaçlı örnekleme yöntemi benimsenmiştir. Amaçlı örneklemde ölçüt olarak lise öğrencilerinde üniversite sınavına girecek olması, üniversite öğrencilerinde KPSS'ye girecek olmaları ölçüt olarak benimsenmiştir.

\section{Veri Toplama Araçları}

Westside Sınav Kaygısı Ölçeği: Orijinali Driscoll (2007) tarafından geliştirilen ölçeğin, Türkçe uyarlaması üniversite öğrencileri için Totan ve Yavuz (2009), lise öğrencileri için Totan (2018) tarafından yapılmıştır. Ölçek 11 maddeden oluşturmaktadır. Uyumun bozulması ve endişenin tek faktör olarak kabul edildiği ölçek 5'li Likert tipi derecelendirmelidir ve (5) Daima Doğru, (4) Genellikle Doğru, (3) Ara Sıra Doğru, (2) Nadiren Doğru ve (1) Asla Doğru Değil şeklinde puanlanmaktadır. Ters kodlanmış maddelerin yer almadığı ölçekten alınabilecek en düşük puan 11, en yüksek puan ise 55'tir. Genel sınav kaygı düzeyinin belirlendiği ölçekte, Cronbach alfa iç tutarlılık katsayısı üniversite öğrencileri için .87 , lise öğrencileri için .91 bulunmuştur. Öğrencilerin sınav kaygısı düzeyleri belirlenirken şu aralıklar göz önünde bulundurulmuştur: Düşük düzey sınav kaygısı: 11.0-25.0 puan aralığı, Orta düzey sınav kaygısı: 26.0-40.0 puan aralığı, Yüksek düzey sınav kaygıs1: 41.0-55.0 puan aralığı. Bu çalışma için ölçeğin iç tutarlılığının bulunması için cronbach alpha katsayısı hesaplanmış ve .85 bulunurken, ölçeğin geçerliği için hesaplanan DFA analizinde ölçeğin bütün maddelerinin anlamlı ve uyum indekslerinin iyi olduğu görülmektedir (X2:79.3, df:44, X2/df:1.8, RMSEA:0.034).

\section{Verilerin Analizi}

Verilerin analizinde, sınav kaygısının okul türleri açısından farklı olup olmadığının belirlenmesi için t testi, yaşın sınav kaygısının yordayıcısı olup olmadığını test etmek için ise basit regresyon analizi benimsenmiş̧ir. Çalışmaların istatistiksel işlemleri Jamovi (2019) programı ile yapılmıştır. Jamovi R (2018) istatistik programı için geliştirilmiş paketleri kullanmaktadır.

\section{Bulgular}

Araştırmada ilk olarak lise ve üniversite öğrencilerinin sınav kaygılarına ilişkin tanımlayıcı istatistiklere yer verilmiştir. Söz konusu tanımlayıcı istatistikler Tablo 1'de verilmiştir.

Tablo 1

Sınav Kaygısına İlişkin Tanımlayıcı istatistikler

\begin{tabular}{llr}
\hline & Okul türü & Sinav Kaygisı \\
\hline \multirow{2}{*}{$\mathrm{N}$} & Üniversite & 260 \\
& Lise & 415 \\
\hline \multirow{2}{*}{ Ortalama } & Üniversite & 35.8 \\
& Lise & 32.1 \\
\hline \multirow{2}{*}{ Ortanca } & Üniversite & 36.0 \\
& Lise & 32.0 \\
\hline \multirow{2}{*}{ Tepe değer } & Üniversite & 37.0 \\
& Lise & 29.0 \\
\hline \multirow{2}{*}{ Standart sapma } & Üniversite & 8.09 \\
& Lise & 8.48 \\
\hline \multirow{2}{*}{ Çarpıklık } & Üniversite & -0.264 \\
& Lise & 0.0142 \\
\hline
\end{tabular}


Tablo 1

Sınav Kaygısına İlişkin Tanımlayıcı istatistikler

\begin{tabular}{llc}
\hline & Okul türü & Sinav Kaygısı \\
\hline \multirow{2}{*}{ Basıklık } & Üniversite & -0.0813 \\
& Lise & -0.432 \\
\hline
\end{tabular}

Tanımlayıcı istatistikler incelendiğinde üniversite öğrencileri için ortalama, tepe değer ve ortancanın birbirine yakın olduğunu söyleyebiliriz. Üniversite öğrencilerinin Skewness (çarpıklık) değerine baktığımızda -0.264 olduğunu görmekteyiz. Eksi değer veri setinin sola çarpık olduğunu bir başka ifade ile verilerin ortalamanın üstünde toplandığını söyleyebiliriz. Lise öğrencilerinin veri seti içinde ortalama, tepe değer ve ortancanın birbirine yakın olduğunu söyleyebiliriz. Lise öğrencilerinin Skewness (çarpıklık) değerine baktı̆̆ımızda 0.0142 olduğunu görmekteyiz. Bir başka ifade ile verilerin sağdan çarpık ve ortalamanın altında olduğunu söyleyebiliriz. Kurtosis değerlerinden verilerin basıklığı incelendiğinde hem lise öğrencilerinin hem de üniversite öğrencilerinin verilerinin pozitif kurtosis değerine sahip olduğu bir başka ifade ile basık bir dağılıma sahip olduğu söylenebilir. Veri setlerinin basıklık ve çarpıklıkları için histogram ve boz plotları şekil 1'de verilmiştir.
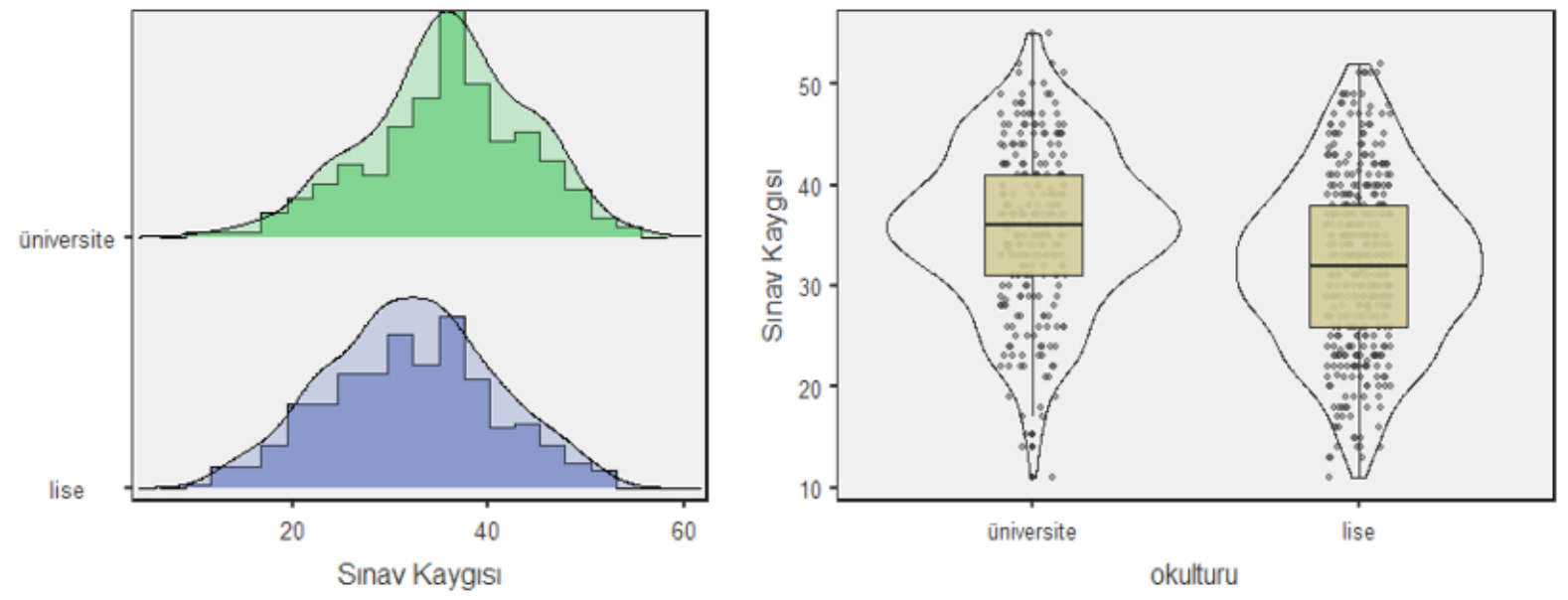

Şekil 1. Sinav Kaygı Verilerinin Histogram ve Box Plotları

Şekil 1'de görüldüğü gibi ver iki grup içinde veri setinin sivri olmadığı ve normal dağılıma yakın verilere sahip olduğu söylenebilir. Ölçeğin kesme puanları dikkatte alınarak veri seti incelendiğinde ise (tablo 1) hem lise öğrencilerinin hem de üniversite öğrencilerinin orta sınav kaygısına sahip olduğu söylenebilir. Lise ve üniversite öğrencilerinin sınav kaygılarının arasında fark olup olmadığını belirlemek için $t$ testi yapılmış ve sonuçlar tablo 2'de verilmiştir.

Tablo 2

Lise Ve Üniversite Öğrencilerinin Sınav Kaygılarına Yönelik T Testi Analizi Sonuçları

\begin{tabular}{ccccccccc}
\hline & & & & \multicolumn{3}{c}{$\% 95$ Güven Aralı̆̆ } & \\
& & t değeri & Ss & p & Alt & Üst & Cohen's d \\
\hline Sinav Kaygisı & t testi & 5.64 & 673 & $<.001$ & 2.42 & 5.01 & 0.446 \\
\hline
\end{tabular}

Ss: Standart Sapma 
Tablo 2 incelendiğinde her iki grup arasında anlamlı bir fark olduğu (t:5.64, p<.05) olduğu görülmektedir. Cohen d değerine bakıldığında 0.44 yani düşük etki düzeyine sahip olduğunu söyleyebiliriz. Bu farkın hangi gruptan kaynaklandığını anlamak için lise ve üniversite öğrencilerinin ortalamaları tablo 3'de verilmiştir.

Tablo 3

Lise ve Üniversite Öğrencilerinin Tanımlayıcı Istatistikleri

\begin{tabular}{llccccc}
\hline & Grup & N & Ortalama & Ortanca & Ss & SH \\
\hline \multirow{2}{*}{ Sinav Kaygis1 } & Üniversite & 260 & 35.8 & 36.0 & 8.09 & 0.501 \\
& Lise & 415 & 32.1 & 32.0 & 8.48 & 0.416 \\
\hline
\end{tabular}

Ss: Standart Sapma, SH: Standart hata

Tablo 3'e bakıldığında, üniversite öğrencilerinin ortalamasının (35.8) lise öğrencilerinin sınav kaygıs1 ortalamalarından (32.1) daha yüksek olduğu görülmektedir. Analizlerin sonunda üniversite öğrencilerinin sınav kaygısı puanlarının lise öğrencilerinin sınav kaygılarından daha yüksek olduğunu görmekteyiz.

Sınav kaygısının yaş ile bir ilişkisinin olup olmadığının belirlenmesi için regresyon analizi yapılmıştır. Regresyon analizinin sonuçları tablo 4 'de verilmiştir.

Tablo 4

Yaşın Sınav Kaygısını Yordamasına İlişkin Regresyon Analizi Sonuçları

\begin{tabular}{|c|c|c|c|c|c|c|c|}
\hline & \multirow[b]{2}{*}{ b } & \multirow[b]{2}{*}{ Sh } & \multicolumn{2}{|c|}{ \%95 Güven Aralı̆̆g } & \multirow[b]{2}{*}{$\mathbf{t}$} & \multirow[b]{2}{*}{$\mathbf{p}$} & \multirow[b]{2}{*}{$\beta$} \\
\hline & & & Alt & Üst & & & \\
\hline Sabit & 20.935 & 2.248 & 16.522 & 25.348 & 9.31 & $<.001$ & \\
\hline Yaş & 0.658 & 0.117 & 0.429 & 0.886 & 5.64 & $<.001$ & 0.213 \\
\hline
\end{tabular}

$R=0.21, R^{2}=0.04, F=31.9$

Tablo 4'de görüldüğü gibi lise ve üniversite öğrencilerinin verileri bölünmeden yapılan analizde öğrencilerin yaşlarının lise ve üniversite öğrencilerinin sınav kaygılarını anlamlı ve pozitif bir şekilde yordadığ bulunmuştur $(\mathrm{t}=5.64, \mathrm{p}<.05) . \mathrm{R}^{2}$ değeri incelendiğinde yaş değişkeninin lise ve üniversite öğrencilerinin sınav kaygısı varyanslarının \%4'ünü açıkladığını görebilmekteyiz.

\section{Tartışma}

Çalışma bulguları incelendiğinde üniversite öğrencilerinin sınav kaygısının lise öğrencilerine oranla daha yüksek ortalamaya sahip olduğunu görebilmekteyiz. T testinden elde edilen sonuca ek olarak regresyon analizi incelendiğinde ise yaş arttıkça sınav kaygısının arttığını görebilmekteyiz. Her iki analizden elde edilen bulgular incelendiğinde üniversite öğrencilerinde sınav kaygısının lise öğrencilerine göre daha yüksek olduğunu görebilmekteyiz ve yaş ile birlikte kayg1 yükselmektedir. İlk akla gelen üniversite sınavına hazırlanan lise öğrencilerinin sınav kaygısının daha yüksek olduğudur. Hatta sınav kaygısı denildiğinde haberlerde, web sitelerinde her yerde karşımıza üniversite sınavına hazırlanan öğrenciler gelmektedir. Fakat üniversite öğrencilerinin sınav maratonları incelendiğinde hatırı sayılır bir sınav maratonunun üniversite öğrencilerini beklediğini görebilmekteyiz. Üniversite sonrası için bir dizi daha merkezi sınav vardır; Kamu Personeli Seçme Sınavı (KPSS), Öğretmenlik Alan Bilgisi Sınavı (ÖABT) Akademik Personel ve Lisansüstü Eğitimi Giriş Sınavı (ALES), Serbest Muhasebeci ve Mali Müşavirlik Sınavı, Yabancı Dil Sınavı (YDS), Yükseköğretim Kurumları Yabancı Dil Sınavı (YÖKDILL), Kaymakamlık: İçişleri Bakanlığı Kaymakam Adaylığı Giriş Sınavı, İSG: İş Sağlığı ve Güvenliği Genel Müdürlüğü İşyeri Hekimliği ve İş Güvenliği Uzmanlığı Sınavı, Mühendislik 
Tamamlama: Teknik Öğretmenler İçin Mühendislik Tamamlama Programları Giriş Sınavı, Sayıştay Başkanlığı Sayıştay Denetçi Yardımcısı Adaylığı Eleme Sınavı gibi sınavlar sadece ÖSYM'nin sitesinde bulunan merkezi olarak yapılan sınavlardır. Bunlara diğer kamu kurumlarının kendi bünyelerinde yaptıkları sınavları, Aktüerlik sınavı, Tıpta uzmanlık sınavını gibi özel ihtisas sınavlarını da ekleyebiliriz. Bir başka ifade ile sınav kaygısı olarak tanımladığımız fenomen ülkemizde üniversiteye girme ile bitmeyen bir durumdur.

Türkiye'de öğretmen adayları, öğretmen olabilmek için Kamu Personel Seçme Sınavına (KPSS) girmek zorundadır. Özellikle bazı branşlarda atanan öğretmen sayısı çok azdır. Bu nedenle, her geçen yıl atama bekleyen öğretmen sayısı artmaktadır. Atanmaları için gereken puanlar yükselmektedir. Öğretmen adaylarının bir kısmı atanabilmek için, özel etüt merkezlerine gitmektedirler. 2016 yılında yayınlanan, "Sözleşmeli Öğretmen İstihdamına İlişkin Yönetmelik" ile öğretmen atamasında KPSS'ye ek olarak sözlü sınav uygulaması getirilmiştir. Gelecekte ne olacaklarını bilememeleri, işsiz kalabilme ihtimali gibi belirsizlikler, öğretmen adaylarının kaygı yaşamasına sebep olmaktadır (Deniz ve Tican, 2017).

Sınav kaygısı ve okul düzeyi ile ilgili çalışmalara bakılınca sonuçların çok tutarlı olmadığı görülmekte. Ergene (2003)'ün yaptığı meta analiz çalışmaya göre ilkokuldan üniversiteye kadar olan okul seviyesinde en yüksek sınav kaygısı üniversite öğrencilerinde görülmektedir. Hembree (1988)'nin yaptığı çalışmada birinci sınıftan lisansüstü seviyeye kadar olan aralıkta sınav kaygısı verisi toplamış ve en fazla çalışmanın üniversite öğrencisinde olduğu görülmüştür. Ergene (2003)'de bu konuya değinmiş üniversite öğrencilerinde sınav kaygısının çok fazla çalışılmamış olduğunu söylemektedir. Okul seviyesi ile ilgili çalışmalar incelendiğinde Güneri (2003)'nin ilkokul, ortaokul ve lise öğrencileri ile yaptığ1 çalışmada, Wigfield ve Eccles (1989)'un ilkokul ve ortaokul öğrencileri ile yaptı̆̆ , Onukwufor ve Ugwu (2018) ortaokul ve lise öğrenciler ile yaptığı, Yenilmez Yenilmez ve Özbey (2006)'in ortaokullarda yaptıkları, Bodas, Ollendick ve Sovani (2008), ile Lowe (2014)'in ortaokul ve lise ögrencileri ile yaptıkları çalışmalarda okul düzeyi arttıkça sınav kaygısının arttığı görülmektedir. Tam tersi olarak Oksal, Durmaz ve Akin (2013)' 'ın yaptığı çalışmada ortaokul ve lise öğrencilerinin sınav kaygılarında bir fark bulunamamıştır. Ek olarak Gürses, Kaya, Doğar, Günes ve Yolcu (2010) ile Mousavi, Haghshenas ve Alishahi (2008) lise türleri arasında farka bakılmış sınav kaygısında fark bulunmamıştır. Hembree (1988)' in meta analiz çalışması incelendiğinde ilkokuldan ortaokula kadar bir yükselme olduğu, bu yükselmenin üniversiteye kadar yatay bir çizgi ile aynı seviyede ilerlediği, üniversite sınavında ise çok az düştügü görülmektedir. Alanyazın tarandığında yabancı çalışmalara paralel bir şekilde sınav kaygısının ülkemizde üniversite öğrencileri ile sıklıkla çalışıldığı ve üniversite öğrencilerinde yüksek olarak yaşandığını görebilmekteyiz (Bahçeci, 2009; Çapulcuoğlu ve Gündüz, 2012; Dündar, Yapici ve Topçu, 2008; Erözkan, 2011; Kavakc1, Güler ve Çetinkaya, 2011; Totan ve Yavuz, 2009). Bunun en önemli nedeninin de yukarıda sayılan üniversiteden sonra yapmak istediği mesleği ile ilgili girmesi gereken sınav sayısının fazlalığı olduğu düşünülmektedir. KPSS üniversite öğrencilerinde önemli bir kaygı kaynağı olmuştur ki özellikle KPSS için geliştirilen sınav kaygıSı ölçeklerini görebilmekteyiz (Karaçanta, 2009; Özsarı, 2008; Ümmet ve Otrar, 2015).

Araştırma bulguları yorumlanırken bulguların Muğla ili ile sınırlı olduğu göz önünde bulundurulmalıdır. Bu sınırlılığının yanında lise ve üniversite çalışma grubunun belirli bölümler ve liseler ile sınırlı olduğu belirtilmelidir. Katılımcılar üniversite ve KPSS'ye girecek öğrencilerden oluştuğu yine diğer sinırlılıklar gibi göz önünde bulundurulmalıdır. Çalışmacıların bu sınırlılıklardan yola çıkılarak farklı il ve kültürlerde de bulguları genelleyebilirler. Farklı ülkelerden karşılaş̧ırmalı çalışmaların yapılması sınav kaygısı alanyazınına katkı sağlayacaktır. Bulguların farklı lise türlerinden elde edilecek veriler ile genellemesi, üniversiteli katılımcılardan ise farklı fakültelerden oluşan katılımcılar ile diğer çalışmaların yapılması önerilmektedir. 


\section{Kaynakça}

Bahçeci, D. (2009). Portfolyo değerlendirmenin sınav kaygısı, çalışma davranışı ve tutum üzerine etkisi. Ahi Evran Üniversitesi Kırşehir Eğitim Fakültesi Dergisi, 10(1), 169-182.

Bodas, J., Ollendick, T. H. ve Sovani, A. V. (2008). Test anxiety in Indian children: A cross-cultural perspective. Anxiety, Stress, \& Coping, 21(4), 387-404. doi: 10.1080/10615800701849902

Buck, R. J. (2017). An investigation of attentional bias in test anxiety. (Doctoral Thesis), University of Manchester, Faculty of Humanities.

Culler, R. E. ve Holahan, C. J. (1980). Test anxiety and academic performance: The effects of studyrelated behaviors. Journal of Educational Psychology, 72(1), 16-20.

Çapulcuoğlu, U. ve Gündüz, B. (2012). Öğrenci tükenmişliğini yordamada stresle başaçıkma, sınav kaygıs1, akademik yetkinlik ve anne-baba tutumları değişkenlerinin incelenmesi. Yayımlanmış Yüksek Lisans Tezi, Mersin: Mersin Üniversitesi Eğitim Bilimleri Enstitüsü.

Deniz, S. ve Tican, C. (2017). Öğretmen adaylarının öğretmen öz-yeterlik inançları ile mesleki kaygılarına yönelik görüşlerinin incelenmesi. Abant İzzet Baysal Üniversitesi Eğitim Fakültesi Dergisi.

Driscoll, R. (2007). Westside test anxiety scale validation. ERIC Digest, ED495968.

Dündar, S., Yapici, Ş. ve Topçu, B. (2008). Üniversite öğrencilerinin bazı kişilik özelliklerine göre sınav kaygısının incelenmesi. Gazi Üniversitesi Gazi Eğitim Fakültesi Dergisi, 28(1).

Ergene, T. (2003). Effective interventions on test anxiety reduction: A meta-analysis. School Psychology International, 24(3), 313-328. doi: 10.1177/01430343030243004

Erözkan, A. (2011). Üniversite öğrencilerinin sınav kaygısı ve başaçıkma davranışları. Sosyal ve Beşeri Bilimler Araştirmalari Dergisi, 1(12).

Güneri, O. (2003). The effect of school level and gender on test anxiety. Education and Science, 28(128), 3-8.

Gürses, A., Kaya, Ö., Doğar, Ç., Günes, K. ve Yolcu, H. H. (2010). Measurement of secondary school students' test-anxiety levels and investigation of their causes. Procedia - Social and Behavioral Sciences, 9, 1005-1008. doi: https://doi.org/10.1016/j.sbspro.2010.12.276

Hembree, R. (1988). Correlates, causes, effects, and treatment of test anxiety. Review of Educational Research, 58(1), 47-77. doi: 10.2307/1170348

Karaçanta, H. (2009). Öğretmen adayları için kamu personeli seçme sınavı kaygı ölçeğının gelıştırılmesı (Geçerlik ve güvenirlik çalişması). Gazi Üniversitesi Endüstriyel Sanatlar Eğitim Fakültesi Dergisi, 25, 50-57.

Kavakcı, Ö., Güler, A. S. ve Çetinkaya, S. (2011). Sınav kaygısı ve ilişkili psikiyatrik belirtiler. Klinik Psikiyatri, 14, 7-16.

Kirkland, K. ve Hollandsworth, J. G. (1980). Effective test taking: Skills-acquisition versus anxietyreduction techniques. Journal of consulting and clinical psychology, 48(4), 431.

Liebert, R. M. ve Morris, L. W. (1967). Cognitive and emotional components of test anxiety: A distinction and some initial data. Psychological Reports, 20(3), 975-978.

Lowe, P. A. (2014). The test anxiety measure for adolescents (TAMA) examination of the reliability and validity of the scores of a new multidimensional measure of test anxiety for middle and high school students. Journal of Psychoeducational Assessment, 32(5), 404-416.

Mandler, G. ve Sarason, S. B. (1952). A study of anxiety and learning. The Journal of Abnormal and Social Psychology, 47(2), 166.

McDonald, A. S. (2001). The prevalence and effects of test anxiety in school children. Educational psychology, 21(1), 89-101.

Mousavi, M., Haghshenas, H. ve Alishahi, M. (2008). Effect of gender, school performance and school type on test anxiety among Iranian adolescents.

Naveh-Benjamin, M., McKeachie, W. J., Lin, Y.-g. ve Holinger, D. P. (1981). Test anxiety: deficits in information processing. Journal of Educational Psychology, 73(6), 816.

Nicaise, M. (1995). treating test anxiety. A review of three approaches. Teacher Education and Practice, $11(1), 65-81$.

Oksal, A., Durmaz, B. ve Akin, A. (2013). SBS'ye hazirlanan ogrencilerin sinav ve matematik kaygilarinin bazi degiskenler acisindan incelenmesi [An investigation into exam and maths anxiety of students preparing for SBS]. Cumhuriyet International Journal of Education, 2(4), 47-62. 
Onukwufor, J. N. ve Ugwu, C. J. (2018). Level of schooling and gender differences in test anxiety among secondary school students in port harcourt local government area of rivers state. Advances in Social Sciences Research Journal, 5(2).

Özsarı, İ. (2008). Egitim fakültesi son sını ögrencilerinin kpss merkezi sınavı odaklı gelecek kaygıları ve mesleki beklentileri. (Yüksek Lisans Tezi), İstanbul Üniversitesi, Sosyal Bilimler Enstitüsü, İstanbul.

Putwain, D. ve Daly, A. L. (2014). Test anxiety prevalence and gender differences in a sample of English secondary school students. Educational Studies, 40(5), 554-570. doi: 10.1080/03055698.2014.953914

Putwain, D. W. (2008). Deconstructing test anxiety. Emotional and Behavioural Difficulties, 13(2), 141 155.

R Core Team (2018). R: A Language and envionment for statistical computing. [Computer software]. https://cran.r-project.org/ adresinden alınmıştır.

Sarason, I. G. (1978). The Test Anxiety Scale: Concept and research. In C. D. Spielberger ve I. G. Sarason (Eds.), Stress and anxiety (Vol. 5, pp. 193-216). Washington DC: Hemisphere Publishing Corp.

Spence, J. T. ve Spence, K. W. (1966). The motivational components of manifest anxiety: Drive and drive stimuli. In C. D. Spielberger (Ed.), Anxiety and behaviour. New York: Academic Press.

Spielberger, C. D. ve Vagg, P. R. (1995). Test anxiety: Theory, assessment and treatment. Bristol: Taylor and Francis.

Suinn, R. M. (1968). The desensitization of test-anxiety by group and individual treatment. Behaviour Research and Therapy, 6(3), 385-387.

The Jamovi Project (2019). Jamovi. (Version 0.9) [Computer Software]. ttps://www.jamovi.org. adresinden alınmıştır.

Totan, T. (2018). Ortaokul ve lise öğrencilerinde sınav kaygısının değerlendirilmesi: Westside sınav kaygısı ölçeği. Batı Anadolu Ĕ̈itim Bilimleri Dergisi, 9(2), 143-155.

Totan, T. ve Yavuz, Y. (2009). Westside sınav kaygısı ölçeğinin Türkçe formunun geçerlik ve güvenirlik çalışması. Mehmet Akif Ersoy Üniversitesi Ë̆itim Fakültesi Dergisi, 9(17), 95-109.

Ümmet, D. ve Otrar, M. (2015). Kamu personeli seçme sınavına (KPSS) yönelik tutum ölçeği geliştirme çalışmasi. Gümüshane Üniversitesi Sosyal Bilimler Enstitüsü Elektronik Dergisi, 6(13), 1-14. doi: $10.17823 /$ gusb.186

Whitaker Sena, J. D., Lowe, P. A. ve Lee, S. W. (2007). Significant predictors of test anxiety among students with and without learning disabilities. Journal of learning disabilities, 40(4), 360-376.

Wigfield, A. ve Eccles, J. S. (1989). Test anxiety in elementary and secondary school students. Educational Psychologist, 24(2), 159-183. doi: 10.1207/s15326985ep2402_3

Wine, J. (1971). Test anxiety and direction of attention. Psychol Bulletin, 76(2), 92. doi:10.1037/h0031332

Yenilmez, K. ve Özbey, N. (2006). Özel okul ve devlet okulu öğrencilerinin matematik kaygı düzeyleri üzerine bir araştırma. Uludă̆ Üniversitesi Ĕgitim Fakültesi Dergisi, 19(2), 431-448.

Zeidner, M. (1998). Test anxiety: The state of the art. New York: Plenum Press. 